Що стосується географії кримінальних правопорушень проти безпеки руху та експлуатації транспорту, то найбільша кількість цих кримінальних правопорушень виявляється у - м. Києві, Дніпропетровській, Одеській, Харківській, Київській та Львівській областях, а найменше у - Луганській, Чернігівській, Тернопільській, Кіровоградській та Хмельницькій областях.

\title{
Література:
}

1. Закалюк А. П. Курс сучасної української кримінології: теорія i практика. У 3 кн. Кн. 1: Теоретичні засади та історія української кримінологічної науки. Київ: Видавничий дім «Ін Юре», 2007. 424 с.

2. Кримінологія : підручник / [Б. М. Головкін, В. В. Голіна, О. В. Лисодєд та ін.]; за заг. ред. Б. М. Головкіна. Харків : Право, 2020. 384 c.

3. Криминология: учебник для вузов / Под общей ред. д. ю. н., проф. А. И. Долговой. 3-е изд., перераб. и доп. М.: Норма, 2007. 912 с.

4. Новіков О. В. Рівень, структура, динаміка кримінальних правопорушень проти безпеки руху та експлуатації транспорту в Україні. Злочинність $i$ протидія п̈й в умовах сингулярності: тендениії та інновачіï: зб. тез доп. наук.-практ. конф., присвяч. пам'яті члена Правління Кримінологічної асоціації України, професора Тетяни Андріївни Денисової (м. Харків, 16 квіт. 2021 р.) / МВС України, Харків. нац. ун-т внутр. справ, Кримінол. асоц. України. Харків : ХНУВС, 2021. 464 c. C. $120-123$.

DOI https://doi.org/10.30525/978-9934-26-074-2-55

\section{ЗАГАЛЬНИЙ ОГЛЯД ПІДСТАВ ДЕКРИМІНАЛІЗАЦІї}

\section{Пустова Н. О.}

аспірантка кафедри кримінального права і кримінології факультету № 1

Інституту з підготовки фахівців для підрозділів Національної поліиії Львівського державного університету внутрішніх справ м. Львів, Украӥна

Підстава - це основний чинник декриміналізації діянь, оскільки саме вона характеризує необхідність зміни кримінального законодавства. У філософії підстава визначається як необхідна умова виникнення буття, пізнання, думки, діяльності тощо [1, с. 614]. Підстава відрізняється від інших умов своєю необхідністю. Отже, підстава - це необхідна умова, 
3 якої обов'язково випливає висновок. Наявність підстави означає наявність дійсної суспільної потреби в кримінально-правовій нормі (або iii скасування). Без підстави не можна декриміналізувати діяння. Однак це не означає, що при наявності підстави діяння буде обов'язково декриміналізоване, оскільки у цьому разі підстава $\epsilon$ необхідна, але недостатня умова - існують також інші умови, що визначають доцільність декриміналізації діянь.

Науковець Злобін Г. А. переконаний, що підстави декриміналізації це соціальні причини втрати нормою здатності адекватно впливати на регульовані суспільні відносини [2].

Суспільна небезпека $є$ найважливішою підставою декриміналізації діянь. Погоджуюся із думкою Панова М. І. та Харитонова С. О. про те, що суспільна небезпечність кримінально-протиправного діяння соціальна (матеріальна) ознака кримінального правопорушення - полягає в тому, що це діяння заподіює чи створює загрозу заподіяння істотної шкоди правам та свободам людини і громадянина, власності, громадському порядку та громадській безпеці, довкіллю, конституційному устрою України, миру, та безпеці людства, іншим охоронюваним законом про кримінальну відповідальність суспільним відносинам. Тому шкода (шкідливість) становить сутність і зміст суспільної небезпечності як ознаки діяння, що визнається кримінальним правопорушенням, органічно притаманна йому, відображає соціальну сутність правопорушення i тому виступає його іманентною властивістю [3].

Слід зазначити, якщо діяння не є суспільно небезпечним, то воно не може бути криміналізоване. Будучи закріпленою в законі та маючи правове значення, ця якість існує об'єктивно й не залежить від волі законодавця або органу, який приймає закони. Діяння небезпечне не тому, що його так оцінив законодавець, а тому, що воно за своїм об'єктивним змістом суперечить нормальним умовам життя суспільства. Соціальну оцінку суспільної небезпечності діяння визначають економічні, політичні, соціально-психологічні, науково-технічні кримінологічні чинники [4].

Кудрявцев В. М. та Ємінов В. Є. визначають декриміналізацію як обгрунтоване виключення з кримінального закону тих діянь, які зараз не становлять суспільної небезпеки. Такі діяння можуть бути переведені в адміністративні проступки, цивільні делікти або взагалі не розглядатися як правопорушення. Підстав цих заходів декілька, причому деякі з них мають суперечливу спрямованість:

a) декриміналізація необхідна при серйозній зміні політичних i економічних відносин у країні; 
б) декриміналізація потрібна, якщо кримінальний закон розходиться із суспільною моральністю;

в) декриміналізація можлива, якщо з небажаними формами поведінки можна вести боротьбу іншими, більш м'якими (i, можливо, більш діючими) засобами, ніж кримінальне покарання;

г) декриміналізація $є$ вимушеною, якщо закон завзято не виконується значною частиною населення [5].

Варто зазначити, що у кримінально-правовій науці $є$ позиції, які фактично ототожнюють підстави і причини декриміналізації. Наумов А. В. хоч і вважає, що підставою декриміналізації є переоцінка ступеня суспільної небезпеки відповідних діянь [6, с. 162], проте водночас переконаний, що причинами декриміналізації є:

1) переконання в неефективності боротьби 3 тими чи іншими діяннями кримінально-правовими засобами;

2) принципова зміна характеру суспільних відносин, які раніше перебували під охороною кримінального закону;

3) зміна уявлень щодо ступеня суспільної небезпечності діяння та його загальноприйнятої моральної оцінки;

4) виконання державою міжнародно-правових зобов'язань щодо охорони прав людини [6, с. 163].

Вважаю, що перераховані вище причини можуть бути віднесені до підстав декриміналізації.

Отже, у кримінально-правовій науці немає єдиного підходу до визначення підстав декриміналізації. Більшість дослідників погоджуються, що обов'язково слід враховувати суспільну небезпеку діяння. Підставами декриміналізації виступають ті явища чи соціальні процеси, які призводять до необхідності звуження рамок кримінально-правової заборони: визнання в певних умовах конкретної кримінально-правової норми неефективною чи необхідність ії зміни, щоб певне коло діянь не вважалося кримінально караним. Крім того, недоцільність чи об'єктивна неможливість боротьби із окремо взятими суспільно небезпечними діяннями засобами кримінального права може також виступати підставою декриміналізації.

\section{Література:}

1. Філософський енциклопедичний словник / НАН України, Ін-т філософії імені Г. С. Сковороди; редкол.: В. І. Шинкарук (голова) та ін. Київ: Абрис, 2002, 742 с.

2. Основания уголовно-правового запрета. Криминализация и декриминализация / П. С. Дагель, Г. А. Злобин, С. Г. Келина, 
Г. Л. Кригер и др.; [отв. ред.: В. Н. Кудрявцев, А. М. Яковлев]. Москва: Наука, 1982. С. 205.

3. Панов М. І., Харитонов С. О. Суспільна небезпечність діяння в системі ознак поняття «кримінальне правопорушення». Проблеми законності. 2020. Вип. 150. С. 130-131.

4. Прозументов Л.М. Общественная опасность как основание криминализации (декриминализации) деяния. Вестник Воронежского института МВД России. 2009. № 4. С. 19.

5. Кудрявцев В.Н., Еминов В.Е. Криминология и проблемы криминализации. Журнал российского права. 2004. № 12. С. 103-107.

6. Наумов А. В. Российское уголовное право. Курс лекций: В 2 т. Т. 1: Общая часть. Москва. Юридиская литература. 2004. 496 с.

DOI https://doi.org/10.30525/978-9934-26-074-2-56

\title{
ВПРОВАДЖЕННЯ ПОЛОЖЕНЬ РИМСЬКОГО СТАТУТУ У ЗАКОНОДАВСТВО УКРАЇНИ - ПРАВОВИЙ ЗАСІБ ВИЗНАННЯ ЮРИСДИКЦІЇ МІЖНАРОДНОГО КРИМІНАЛЬНОГО СУДУ
}

\author{
Ситник В. А. \\ аспірант кафедри кримінального права № 1 \\ Начіонального юридичного університету імені Ярослава Мудрого
}

\section{Борисов В. I.}

доктор юридичних наук,

професор кафедри кримінального права № 1

Національного юридичного університету імені Ярослава Мудрого м. Харків, Україна

У 1998 році Генеральна Асамблея ООН скликала конференцію метою якої було утворення Міжнародного кримінального суду. 17 липня 1998 року було прийнято Римський статут, який вступив в силу 1 липня 2002 року після ратифікації 60 країнами, Цей нормативно-правовий акт став основою для заснування першого i постійно діючого кримінального суду.

Воєнні правопорушення $є$ найпоширенішою складовою основних міжнародних злочинів. Також слід зазначити, що воєнні злочини були визначені в нормах міжнародного гуманітарного права та регулю- 